\title{
STUDI PARAMETRIK PENGARUH VARIASI TINGKATAN BEBAN AKSIAL TERHADAP PERILAKU LENTUR DAN AKSIAL PENAMPANG KOLOM BETON BERTULANG DENGAN BEBAN SIKLIK
}

\author{
Agung Adrian Qausar ${ }^{1}$, Rendy Thamrin ${ }^{2}$, dan Jati Sunaryati ${ }^{3}$
}

\begin{abstract}
ABSTRAK
Pada studi ini dilakukan analisis lentur dan aksial penampang kolom beton bertulang akibat beban siklik dengan hasil berupa respons momen kurvatur dan deformasi aksial. Suatu program komputer RCCSA V.4.3 berbasis metode diskrit elemen telah dikembangkan untuk keperluan tersebut. Model hsiteresis material untuk beton dan baja tulangan menggunakan model yang diajukan peneliti sebelumnya dengan beberapa modifikasi dan penyesuaian Dari hasil analisis dengan variasi tingkatan beban aksial sebesar $20 \%, 30 \%$ dan $40 \%$ dari kapasitas aksial penampang diketahui bahwa peningkatan beban aksial akan menurunkan daktilitas lentur dari penampang kolom. Penampang kolom dengan penulangan under reinforced memilki daktilitas paling baik dalam menerima beban aksial dan lateral siklik seperti terlihat dari rasio $\left(\phi_{\text {ult }} / \phi_{\text {yield }}\right)$ yang lebih besar. Perubahan signifikan pada respons deformasi aksial-kurvatur kolom terjadi ketika beban aksial yang bekerja telah lewat 30\% dari kapasitas rencana, hal ini menandakan kinerja kolom dalam memikul beban sudah jauh berkurang pada tingkatan beban tersebut.
\end{abstract}

Kata kunci : model histeresis material; beban siklik; beban aksial; momen kurvatur; regangan aksial.

\section{PENDAHULUAN}

Kapasitas memikul beban sekaligus perilaku disipasi energi dari penampang kolom dalam kondisi deformasi pasca leleh memiliki peranan penting untuk mencegah keruntuhan total dari struktur beton bertulang. Karakteristik histeresis seperti kekakuan, daktilitas, dan disipasi energi menjadi perhatian penting terkait dengan kinerja kolom dalam memikul beban dinamis seperti beban gempa. Akibat beban gempa, struktur kolom akan menerima beban lateral siklis (bolak-balik) dan ketika beban gempa bekerja dalam arah vertikal kolom akan menerima beban aksial yang bervariasi dan ada kemungkinan beban aksial yang bekerja akan melebihi kapasitas rencana

Seiring perkembangan teknologi komputasi, banyak kajian numerik yang dilakukan yang bermanfaat untuk memprediksi perilaku elemen struktur beton bertulang. Simulasi numerik ini sangatlah penting dalam pemeriksaan kapasitas dan kinerja dari elemen struktur kolom yang menerima kombinasi beban lateral dan aksial. Untuk meneliti pengaruh dari variasi beban aksial terhadap perilaku lentur dan aksial tersebut dalam paper ini dilakukan suatu analisis penampang dengan metode diskrit elemen dengan memvariasikan besar beban aksial dan tipe pembebanan lateral yang bekerja pada kolom beton bertulang. Permodelan histeresis material mengacu pada

\footnotetext{
${ }^{1}$ Mahasiswa Pasca Sarjana Teknik Sipil Universitas Andalas,agungqausar@gmail.com

${ }^{2}$ Staf Pengajar Jurusan Teknik Sipil Fakultas Teknik Universitas Andalas, rendy@ft.unand.ac.id

${ }^{3}$ Staf Pengajar Jurusan Teknik Sipil Fakultas Teknik Universitas Andalas, jati@ft.unand.ac.id
} 
model yang telah dikembangkan peneliti sebelumnya yakni Esmaily, A., Xiao, Y., (2005) dan Thamrin, R.,(2006), dengan beberapa modifikasi dan penyesuaian.

\section{PERMODELAN HISTERESIS MATERIAL}

\subsection{Model Material Beton}

Model histeresis beton yang digunakan dalam penelitian ini menggunakan modifikasi dari model model histeresis beton terkekang yang diajukan oleh Esmaily, A. dan Xiao, Y. (2005). Berikut adalah sampel kurva histeresis berdasarkan model tersebut:

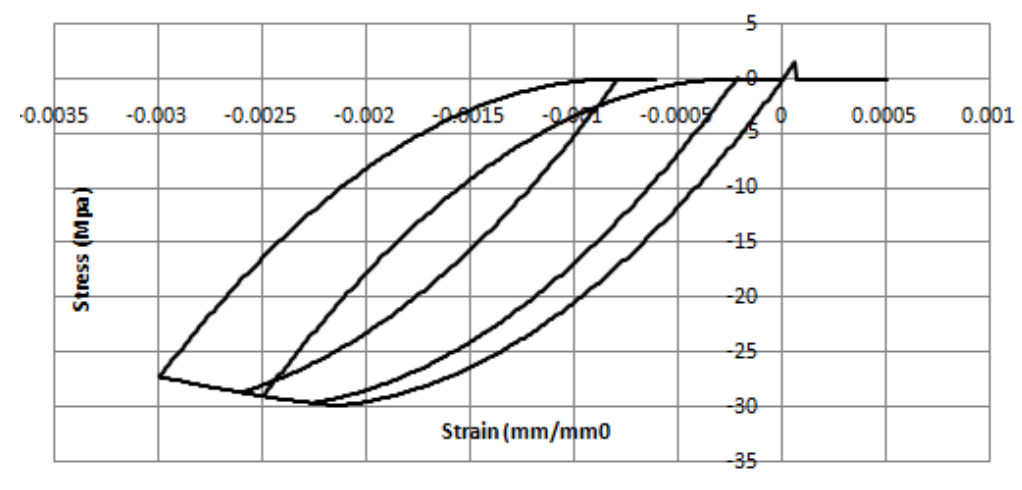

Gambar 1: Model histeresis material beton

Pada model siklik tersebut kurva monotonik dari beton menggunakan model beton terkekang dari Mander (1988), pada saat terjadi unloading kurva akan turun secara parabolik sesuai persamaan tegangan-regangan material oleh Esmaily, A., Xiao, Y., (2005), jika beton telah retak atau kuat tariknya terlampaui, tegangan tarik beton akan selalu bernilai nol pada model, dengan demikian mengabaikan sepenuhnya dampak dari tension stiffening, sementara pada model untuk analisis modifikasi dilakukan dengan mempertimbangkan tension stiffening effect pada daerah tarik dari beton, modifikasi dilakukan pada model histeresis tersebut sehingga ketika tegangan tarik terlampaui kuat tarik tidak akan langsung bernilai nol tapi akan menurun secara perlahan dan diasumsikan turun secara linier.

\subsection{Model Material Baja}

Model histeresis baja tulangan menggunakan model multilinier oleh Thamrin, (2006) yang mengacu pada model trilinier yang diajukan Esmaily, A., dan Xiao, Y, (2005), dengan beberapa modifikasi. Pada model ini digunakan tujuh parameter yang digunakan untuk menyesuaikan kemiringan dan inklinasi dari respons tegangan-regangan baja, yakni: $P_{1}, P_{2}, P_{3}, R_{1}, R_{2}, R_{3}$, and $R_{4}$, kemudian perubahan garis dapat dihitung dengan persamaan:

$$
\begin{aligned}
& L_{1}=\left(P_{1} \cdot f_{y}\right)-\left(\varepsilon_{i} \cdot f_{u}\right) \\
& L_{2}=\left(P_{2} \cdot f_{y}\right)-\left(\varepsilon_{i} \cdot f_{u}\right) \\
& L_{3}=\left(P_{3} \cdot f_{y}\right)-\left(\varepsilon_{i} \cdot f_{u}\right)
\end{aligned}
$$

\section{8 | JURNAL REKAYASA SIPIL}


Qausar, A., Thamrin, R., Sunaryati, J.

$$
\begin{aligned}
& L_{4}=-\left(P_{1} \cdot f_{y}\right)-\left(\varepsilon_{i} \cdot f_{u}\right) \\
& L_{5}=-\left(P_{2} \cdot f_{y}\right)-\left(\varepsilon_{i} \cdot f_{u}\right) \\
& L_{5}=-\left(P_{3} \cdot f_{y}\right)+\left(\varepsilon_{i} \cdot f_{u}\right)
\end{aligned}
$$

Dengan : $P_{1}=0.2, P_{2}=0.85, P_{3}=1.05, R_{1}=0.65, R_{2}=0.325, R_{3}=0.25$, and $R_{4}=0.125$. Seperti yang dapat dilihat pada gambar 2 , modulus elastisitas yang sama digunakan pada garis loading dan unloading hingga tegangan mencapai garis peubah pertama ( $L_{1}$ atau $\left.L_{4}\right)$. kemudian kekakuan berubah menjadi $R_{1} E_{s}$ atau $R_{3} E_{s}$ hingga tegangan mencapai garis peubah kedua $\left(L_{2}\right.$ or $\left.L_{3}\right)$. Pada akhirnya parameter $R_{2}$ and $R_{4}$ digunakan untuk mengubah besar kekakuan hingga tegangan mencapai garis $L_{3}$ or $L_{6}$. Titik potong dari respons histeresis utuk setiap garis dapat diatur masingmasing dengan parameter $P_{1}, P_{2}$, and $P_{3}$.

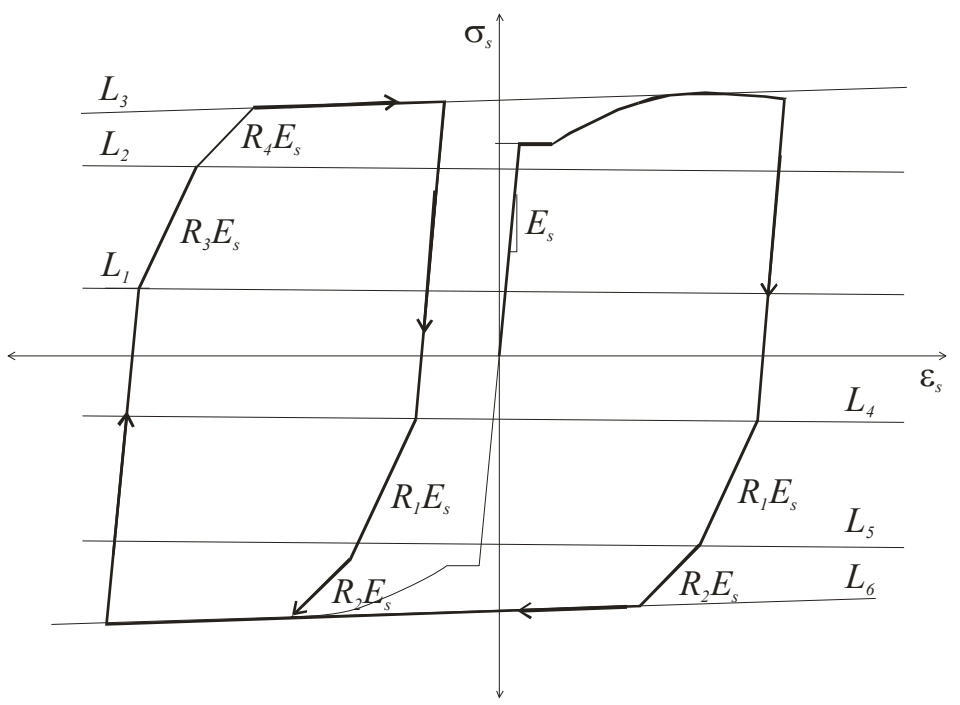

Gambar 2: Model histeresis material baja tulangan, Thamrin, R. (2006)

\section{ANALISIS PENAMPANG}

Analisis penampang dilakukan dengan metode diskrit elemen, pada metode ini penampang dibagi menjadi elemen-elemen berlapis. Untuk setiap nilai peningkatan regangan, berdasarkan model histeresis material yang dipakai dapat diketahui besar tegangan pada masing-masing elemen sehingga resultan gaya total yang bekerja pada penampang dapat dihitung. Distribusi teganganregangan kemudian flowchart prosedur perhitungan dapat dilihat pada gambar 3 dan 4 . 

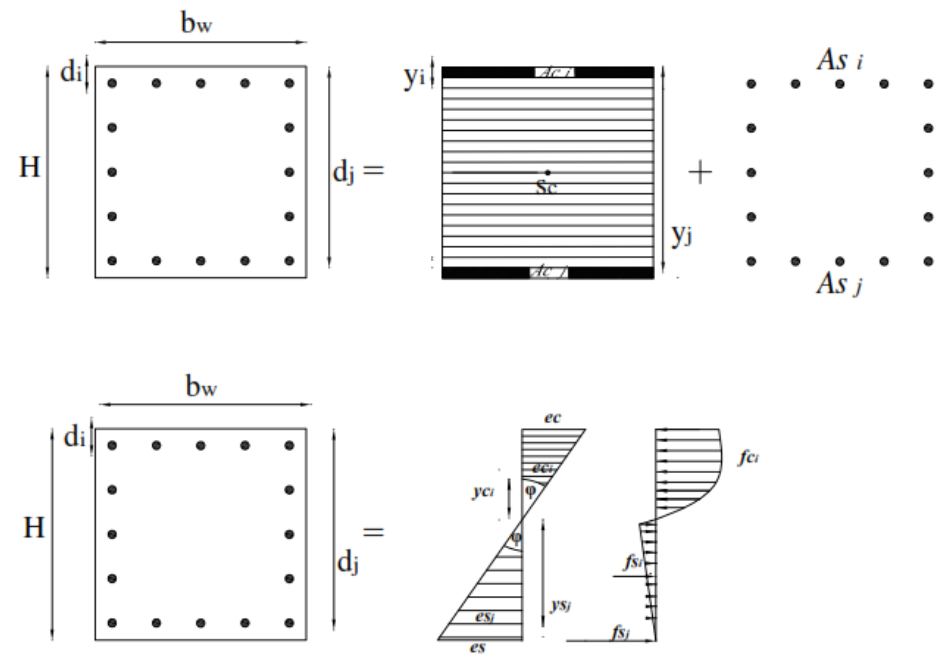

Gambar 3: Distribusi regangan dan tegangan pada penampang pada metode diskrit elemen dengan mempertimbangkan kuat tarik beton

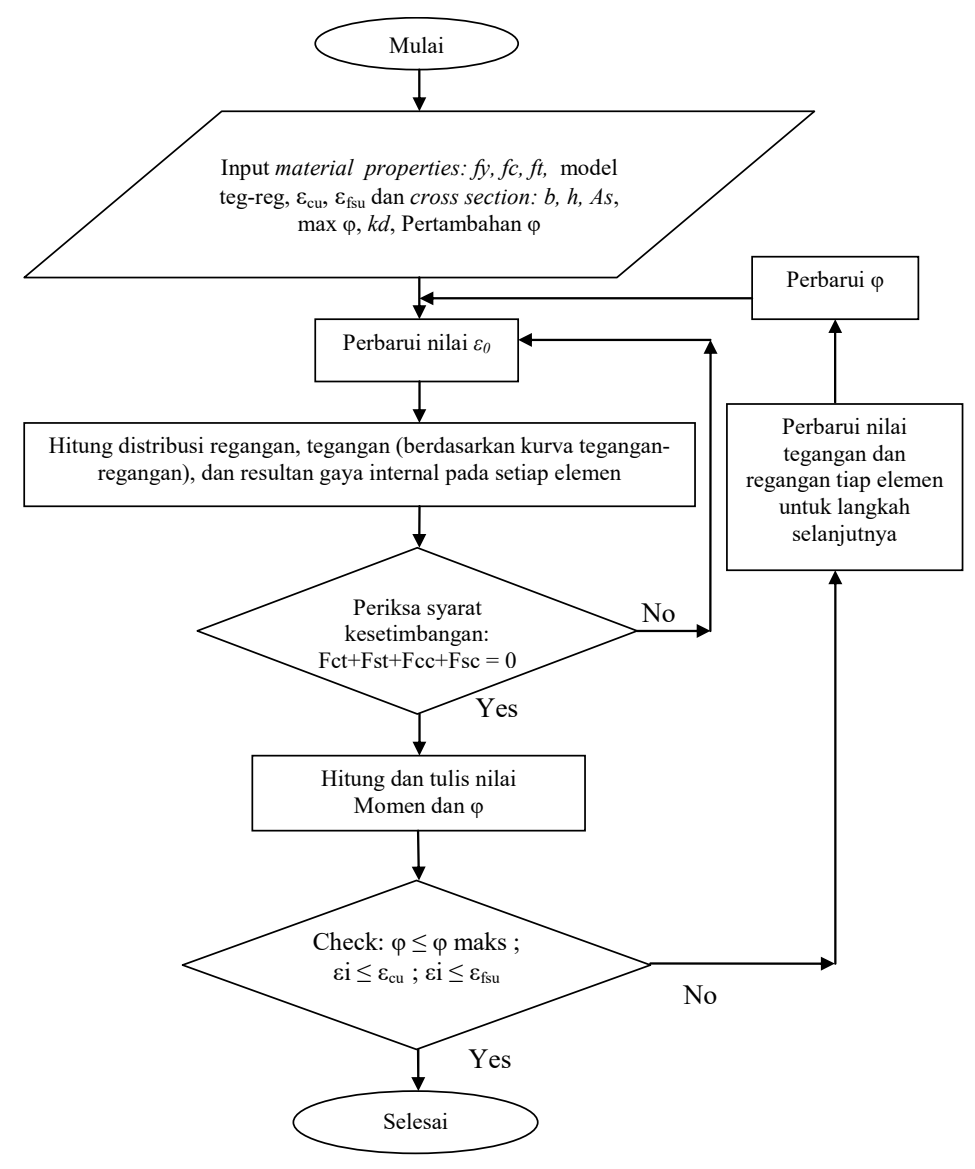

Gambar 4: Flowchart prosedur analisis penampang 


\section{HASIL DAN PEMBAHASAN}

Pengaruh beban aksial $(\mathrm{P})$ pada kolom akan dievaluasi dengan melakukan simulasi numerik berupa analisis penampang dengan beban siklik pada kolom persegi dengan dimensi 500x500 mm. Kuat tekan beton ditetapkan sebesar $30 \mathrm{Mpa}$, dengan variasi rasio tulangan masing-masing terdiri atas tiga tipe keruntuhan, yakni under reinforced, balance dan over reinforced dengan tegangan leleh $f y=410 \mathrm{Mpa}$. Kolom mula-mula tidak diberi beban aksial, kemudian diberi beban aksial sebesar $20 \%, 30 \%, 40 \%$ dari kapasitas aksial penampang $(P n=A g . f c)$ Detail penampang dan konfigurasi tulangan dapat dilihat pada gambar 5 berikut riwayat pembebanan pada gambar 6 . Hasil analisis berupa respons deformasi aksial-kuvatur dan momen-kurvatur dapat dilihat pada gambar 7 dan 8 .

Ketika penampang dibebani secara siklik tanpa diberi beban aksial atau dalam kondisi momen murni, regangan aksial pada penampang kolom tanpa beban aksial berperilaku seperti penampang balok, regangan aksial pada penampang dengan penulangan under reinforced lebih besar dibanding penampang bertulangan seimbang maupun lebih, ini dapat dimengerti karena luas tulangan yang lebih sedikit maka tulangan dengan penulangan under reinforced lebih dulu mengalami leleh, ketika baja telah sampai pada regangan lelehnya garis netral menjalar ke serat tekan terluar sehingga regangan aksial yang terjadi pada penampang under reinforced lebih besar.
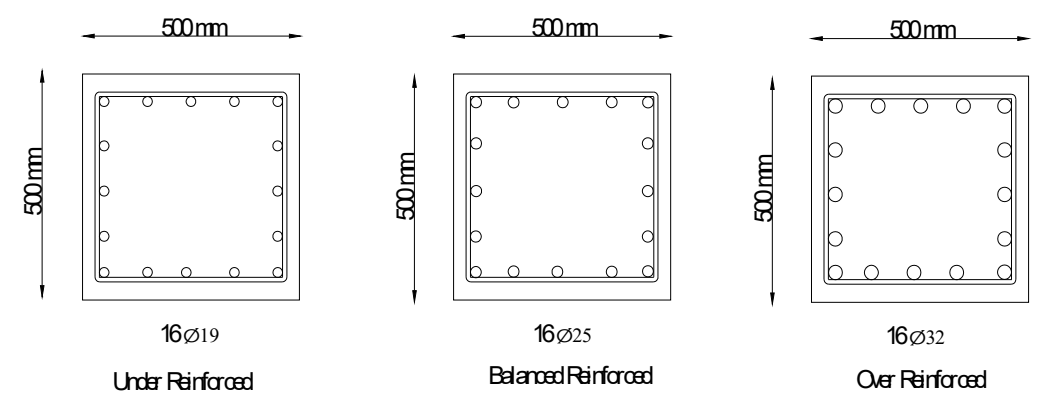

Gambar 5: Detail penampang berikut konfigurasi tulangan dari penampang kolom

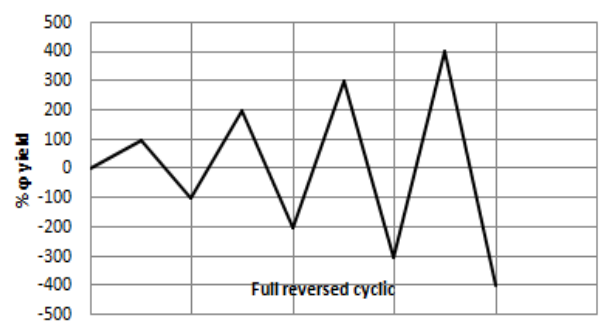

Gambar 6: Riwayat Pembebanan Pada Analisis Penampang

Beban siklik yang diterapkan pada analisis ditetapkan sedemikian rupa dengan menjadikan nilai 甲yield sebagai acuan. Material properties dan rasio tulangan berikut besar beban aksial yang diberikan diperlihatkan pada tabel 1 . 
Tabel 1. Data Spesimen Pengujian Pengaruh Beban Aksial

\begin{tabular}{|l|c|c|c|c|c|}
\hline No. & $\begin{array}{c}\text { Penampang } \\
\text { Kolom }\end{array}$ & $\begin{array}{c}\text { fc } \\
\text { (Mpa) }\end{array}$ & $\begin{array}{c}\text { fy } \\
\text { (Mpa) }\end{array}$ & $\boldsymbol{\rho}$ & $\boldsymbol{P}(\%)$ \\
\hline 1 & K00-U & 30 & 410 & 0.0181 & 0 \\
2 & K00-B & 30 & 410 & 0.0314 & 0 \\
3 & K00-O & 30 & 410 & 0.0514 & 0 \\
4 & K20-U & 30 & 410 & 0.0181 & 20 \\
5 & K20-B & 30 & 410 & 0.0314 & 20 \\
6 & K20-O & 30 & 410 & 0.0514 & 20 \\
7 & K30-U & 30 & 410 & 0.0181 & 30 \\
8 & K30-B & 30 & 410 & 0.0314 & 30 \\
9 & K30-O & 30 & 410 & 0.0514 & 30 \\
10 & K40-U & 30 & 410 & 0.0181 & 40 \\
11 & K40-B & 30 & 410 & 0.0314 & 40 \\
12 & K40-O & 30 & 410 & 0.0514 & 40 \\
\hline
\end{tabular}

Catatan: $\rho b=0.0314$

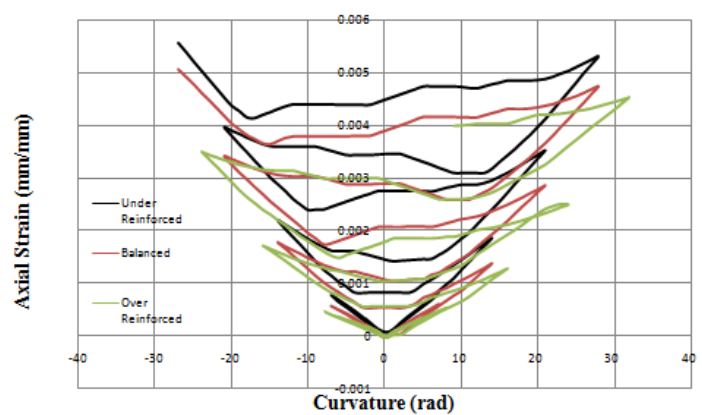

(a)

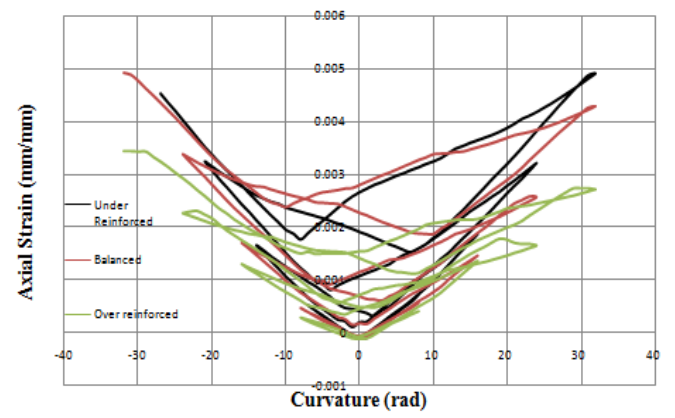

(c)

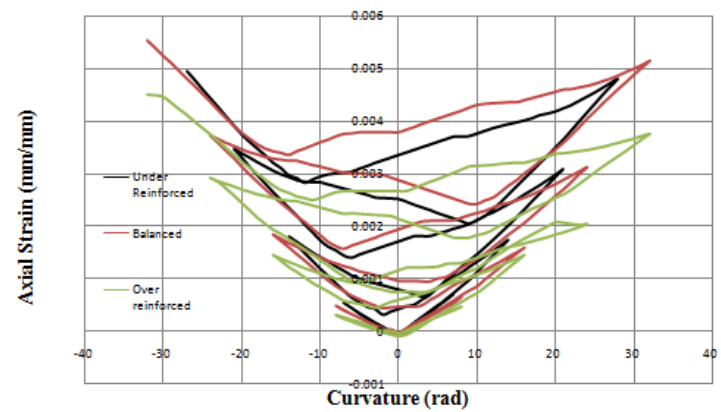

(b)

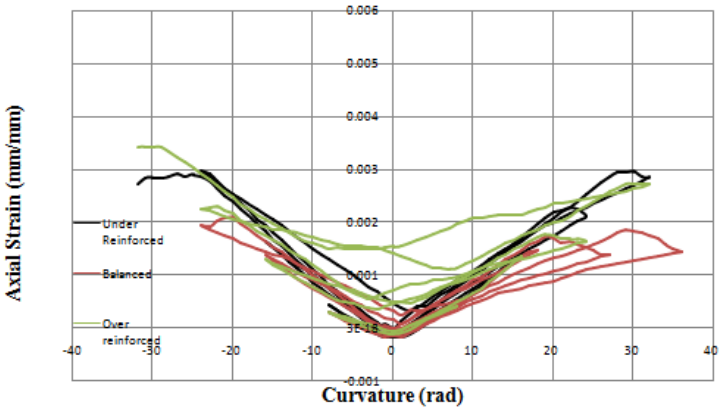

(d)

Gambar 6: Respons deformasi aksial-kurvatur dengan variasi rasio penulangan untuk tiap tingkatan beban aksial; (a) 0 , (b) $20 \%$, (c) $30 \%$, (d) $40 \%$

Pada saat diberi beban aksial $\left(P=0.2 . A g . f c^{\prime}\right)$ dan $\left(P=0.3 . A g . f c^{\prime}\right)$ kolom menerima gaya aksial tekan yang besar namun regangan yang terjadi belum signifikan, ketika beban aksial mencapai $(P=0.4 . A g . f c)$ pertambahan regangan meningkat lebih drastis berbeda dengan sebelumnya, pada titik ini deformasi aksial sudah cukup besar ditandai dengan regangan aksial yang bernilai dibawah 
nol yang menandakan pada titik tersebut sebagian beton pada kolom telah hancur dan umumnya kolom telah telah mengalami deformasi yang besar akibat kombinasi beban aksial dan lateral siklik sejalan dengan kapasitas dari penampang yang sudah jauh berkurang dalam memikul beban.

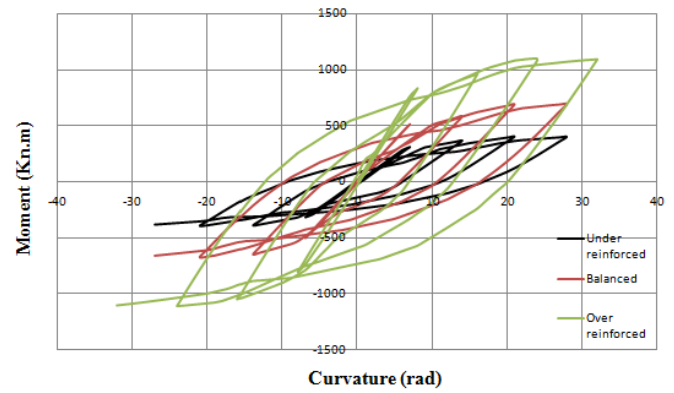

(a)

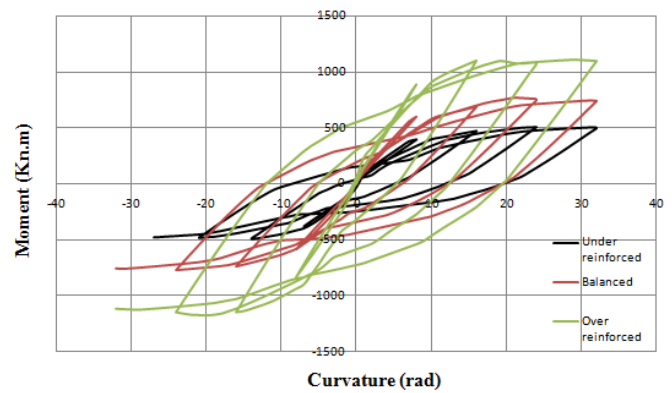

(c)

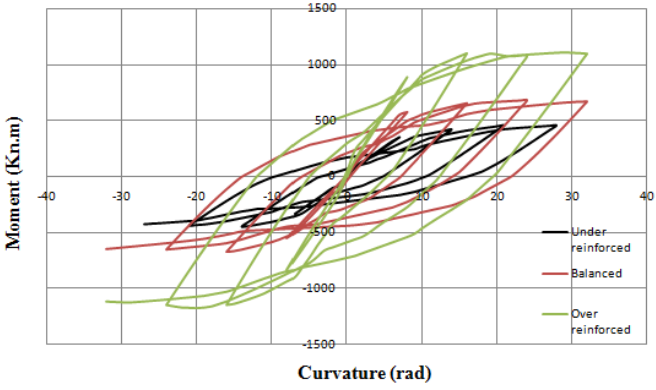

(b)

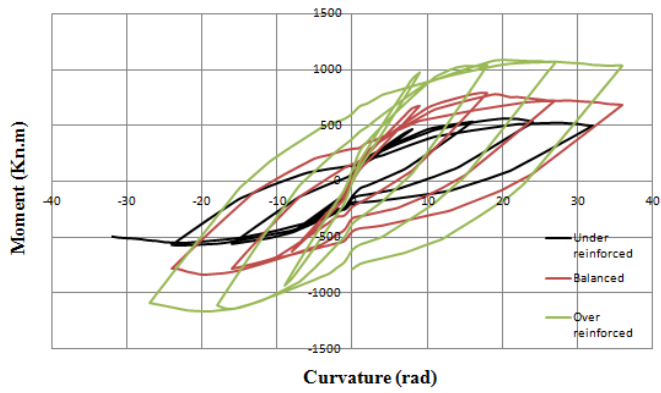

(d)

Gambar 7: Respons momen-kurvatur dengan variasi rasio penulangan untuk tiap tingkatan beban aksial (a) 0 , (b) $20 \%$, (c) $30 \%$, (d) $40 \%$

Dari respons momen kurvatur, perilaku disipasi energi dan daktilitas dari penampang kolom secara visual dapat dilihat pada kurva histeresis. Penampang bertulangan lebih memiliki kemampuan disipasi energi yang lebih besar dibanding penampang bertulangan seimbang dan under reinforced akan tetapi penampang bertulangan under reinforced memiliki daktilitas yang lebih dibanding penampang dengan penulangan seimbang atau lebih. Seiring peningkatan beban aksial terjadi penurunan rasio daktilitas lentur $\left(\phi_{\text {ult }} / \phi_{\text {yield }}\right)$ penampang. Pada penampang dalam kondisi tanpa beban aksial, penampang under reinforced memiliki rasio daktilitas $\left(\mu=\phi_{\text {ult }} / \phi_{\text {yield }}=6\right)$, penampang bertulangan seimbang $\left(\mu=\phi_{\text {ult }} / \phi_{\text {yield }}=4,3\right)$ sedangkan penampang over reinforced $(\mu=$ $\left.\phi_{\text {ult }} / \phi_{\text {yield }}=2,86\right)$.

\section{KESIMPULAN}

Penelitian yang dilaporkan pada paper ini berupa hasil analisis dan pengamatan mengenai perilaku penampang kolom yang dibebani secara aksial dan lateral siklik dengan tiga variasi tipe penulangan. Berdasarkan hasil penelitian dapat ditarik beberapa kesimpulan, yakni:

1. Regangan aksial penampang kolom dipengaruhi oleh rasio penulangan dan rasio beban aksial yang bekerja. Besar regangan aksial berkurang akibat meningkatnya beban aksial.

VOLUME 12 NO. 2, OKTOBER 2016 | 13 
2. Perubahan drastis pada respons aksial dan kurvatur penampang terjadi ketika beban aksial yang bekerja telah melewati 30\% kapasitas aksial penampang.

3. Beban aksial yang bekerja menurunkan daktilitas lentur penampang.

4. Penampang bertulangan over reinforced memiliki kemampuan disipasi energi paling besar jika dibandingkan dengan penampang bertulangan seimbang dan under reiforced.

5. Penampang kolom dengan penulangan under reinforced memilki daktilitas paling baik dalam menerima beban aksial dan lateral siklik memiliki rasio $\left(\phi_{\text {ult }} / \phi_{\text {yield }}\right)$ paling besar, pada penampang under reinforced memiliki rasio daktilitas $\left(\mu=\phi_{\text {ult }} / \phi_{\text {yield }}=6\right)$, penampang bertulangan seimbang $\left(\mu=\phi_{\text {ult }} / \phi_{\text {yield }}=4,3\right)$ sedangkan penampang over reinforced $(\mu=$ $\left.\phi_{\text {ult }} / \phi_{\text {yield }}=2,86\right)$.

\section{UCAPAN TERIMAKASIH}

Penulis mengucapkan terimakasih kepada para peneliti sebelumnya karena dengan hasil kerja keras mereka analisis pada studi ini dapat penulis lakukan. Penulis juga berterimkasih kepada Bapak Rendy Thamrin Dr. Eng selaku penulis kedua yang telah mau memodifikasi perangkat lunak RCCSA sehingga dapat mempermudah penulis dalam melakukan analisis dan Ibu Jati Sunaryati, $\mathrm{Ph} . \mathrm{D}$ yang juga telah banyak memberikan kontribusi berarti sehingga penulis dapat menyelesaikan studi ini.

\section{DAFTAR KEPUSTAKAAN}

Esmaily, A., Yan Xiao, 2002, "Seismic Behavior Of Bridge Columns Subjected To Various Loading Patterns", PEER Report, Pacific Earthquake Engineering Research Center, University Of California, Barkeley.

Esmaily, Yan Xiao, 2005, "Behavior of Concrete Columns Under Variable Axial Loads", ACI Structural Journal, V. 102, No. 5

Mander J. B., Priestley, M. J. N., Park, R., "Theoritical Stress-Strain Model for Confined Concrete", ASCE Structural Journal, V. 114, No. 8, pp 1804-1826

Thamrin. R., 2006, "Flexural and Bond Behavior of Reinfored Concrete Beams with FRP Bars", Doctoral Thesis, Toyohashi University of Technology, Toyohashi, Japan.

Thamrin. R., 2015, Reinforced Concrete Cross Section Analysis (RCCSA), User Manual, Universitas Andalas, Padang. 